\title{
Influence of Long-term Changes of Sea-Surface Temperature on the State of Some Fish Stocks in the Northwest Atlantic
}

\author{
A. P. Baidalinov \\ Atlantic Scientific Research Institute of Marine Fisheries and Oceanography (AtlantNIRO) \\ 5 Dmitry Donskoy Street, Kaliningrad 236000, Russia
}

\begin{abstract}
The changes in spawning biomass of the northern stock cod in Canadian waters and cod biomass off West Greenland were compared with the changes of sea-surface temperatures (SST)in the Irminger Sea. The correlation between variations of SST and cod biomass during the period 1956-88 in these areas indicated the influence of climatic changes on the status of the spawning stock of cod in the Newfoundland area and the cod stock at West Greenland. Similar correlations were observed in the variations of SST during the period 1977-88 in the Scotian Shelf area and the status of the silver hake stock.
\end{abstract}

\section{Introduction}

Over the recent 30 years, considerable changes in the status of stocks of some commercial fish species in the Northwest Atlantic have been reported. The changes in the biomass of particularly the northern spawning stock of cod off Newfoundland (FO'S'CLE, 1988), cod stock at West Greenland (Schumacher, MS 1988) and the silver hake stock on the Scotian Shelf (Fanning et al. MS 1987; Noskov, MS 1987) have been of significant interest in recent years. In the late-1970s and early-1980s these stocks were reduced to their minimum levels, followed by marked increases in the mid-1980s. There have been differing viewpoints concerning the causes of these changes. While various abiotic and biotic factors are often considered to have effects on the status of the stocks, one of the causes is also thought to be the introduction in 1977 of the Extended Jurisdiction of Coastal States to 200-miles from the coastline and the subsequent fishery regulatory measures and fishing practices. The overall effect of such factors are difficult, if not impossible to evaluate, however, consideration of individual factors are often possible and practical.

The present report considers the relationship of one environmental parameter, water temperature, in relation to the status of these three fish stocks.

\section{Materials and Methods}

Mean monthly sea surface temperatures (SST) from the centres of each $5^{\circ}$ quadrants of latitude and longitude on the Scotian Shelf $\left(40-45^{\circ} \mathrm{N}, 60-\right.$ $\left.65^{\circ} \mathrm{W}\right)$ and in the Irminger Sea $\left(55-60^{\circ} \mathrm{N}, 30-35^{\circ} \mathrm{W}\right.$ were obtained from the Hydrometeocenter of the Union of Soviet Socialist Republics. Information on the status of the three stocks was obtained from published literature. Silver hake biomass estimates were from Fanning et al. (MS 1987) and Noskov (MS 1987), while the biomass estimates of the northern spawning stock of cod off Newfoundland were from FO'C'SLE (1988) and the West Greenland cod stock were from Schumacher (MS 1988) and other papers.

The SSTs are considered as indexes reflecting the interaction of oceanolographic systems. The systems relevant to this study consist of: the admixture of warm Gulf Stream waters and cold waters of the Labrador Current in the Nova Scotian Shelf area; warm waters of the North Atlantic Current merging with the Irminger Current and cold polar and Labrador waters in the Irminger Sea and West Greenland areas. Integral curves of the water temperature anomalies at the sea surface were therefore prepared. This technique is widely accepted in studies of global variations of the oceanolographic and hydrometeorlogical factors in the North Atlantic (Zverev, 1972; Girs, 1971).

The integral curves are good for identification of intensifications (when positive values of anomalies are recorded), weakening (when negative values of anomalies are recorded) or stabilization (when small departures are recorded in the anomalies) of the SST.

The increase of the sum of water temperature anomalies on the Scotian Shelf is considered to be the result of intensification of the Gulf Stream influence (approaching closer to the Shelf) while the decrease is assigned to increased influence of the cold Labrador Current. Similarly, the rise of the water temperatures in the Irminger Sea can be attributed to the increased effect of the warm Irminger Current and the movement of the subpolar front to the north and west, while the drop of tem- 
TABLE 1. Change of sum of SST anomalies in the Irminger Sea from 1977 to 1988.

\begin{tabular}{|c|c|c|c|c|c|c|c|c|c|c|c|c|}
\hline Month & 1977 & 1978 & 1979 & 1980 & 1981 & 1982 & 1983 & 1984 & 1985 & 1986 & 1987 & 1988 \\
\hline 1 & -0.7 & -0.1 & -1.5 & 0.4 & 5.4 & 6.6 & 1.8 & -4.9 & -11.3 & -12.7 & -20.8 & -21.6 \\
\hline 2 & -1.0 & -0.1 & -0.4 & 0.2 & 5.5 & 6.8 & 1.1 & -5.5 & -11.1 & -12.5 & -22.0 & -23.0 \\
\hline 3 & -1.5 & 0.0 & -0.3 & 1.1 & 5.3 & 6.7 & 0.6 & -6.6 & -11.4 & -13.1 & -22.7 & -23.6 \\
\hline 4 & -1.4 & -0.1 & 0.7 & 1.3 & 5.0 & 6.1 & 0.2 & -7.3 & -11.8 & -13.8 & -22.2 & -24.4 \\
\hline 5 & -1.5 & 0.1 & 1.3 & 1.7 & 4.7 & 5.1 & -0.7 & -8.0 & -12.3 & -15.4 & -22.5 & -24.5 \\
\hline 6 & -1.7 & -0.7 & 1.7 & 2.8 & 4.5 & 4.7 & -1.2 & -8.8 & -12.5 & -16.1 & -21.4 & -23.9 \\
\hline 7 & -1.7 & -1.2 & 1.2 & 2.8 & 5.0 & 4.9 & -2.3 & -9.7 & -13.2 & -17.5 & -20.9 & -25.5 \\
\hline 8 & -1.2 & -1.1 & 0.8 & 3.8 & 4.4 & 4.2 & -3.9 & -9.9 & -13.8 & -18.2 & -19.4 & -26.6 \\
\hline 9 & -1.1 & -0.6 & 0.6 & 4.3 & 4.8 & 3.6 & -4.0 & -10.4 & -13.7 & -18.3 & -19.2 & -26.3 \\
\hline 10 & -1.1 & -0.3 & 0.5 & 4.3 & 5.2 & 2.8 & -4.5 & -11.0 & -13.5 & -18.8 & -20.5 & -26.1 \\
\hline 11 & -0.7 & -0.3 & 0.3 & 4.6 & 5.4 & 2.4 & -4.8 & -11.2 & -13.1 & -19.7 & -21.3 & -26.1 \\
\hline 12 & -0.2 & -0.8 & 0.1 & 5.1 & 5.9 & 1.5 & -4.4 & -11.3 & -12.7 & -20.2 & -21.3 & -25.3 \\
\hline \multicolumn{13}{|l|}{---- } \\
\hline $1-3$ & -1.1 & -0.1 & -0.7 & 0.6 & 5.4 & 6.7 & 1.2 & -5.7 & -11.3 & -12.8 & -21.8 & -22.7 \\
\hline $4-6$ & -1.5 & -0.3 & 1.2 & 1.9 & 4.7 & 5.3 & -0.6 & -8.0 & -12.2 & -15.1 & -22.0 & -24.3 \\
\hline $7-9$ & -1.3 & -1.0 & 0.9 & 3.6 & 4.7 & 4.6 & -3.4 & -10.0 & -13.6 & -18.0 & -19.8 & -26.1 \\
\hline $10-12$ & -0.7 & -0.5 & 0.3 & 4.7 & 5.5 & 22.0 & -4.6 & -11.2 & -13.1 & -19.6 & -21.0 & -25.8 \\
\hline \multicolumn{13}{|l|}{---- } \\
\hline $1-12$ & -1.2 & -0.5 & 0.4 & 2.7 & 5.1 & 4.7 & -1.8 & -8.7 & -12.6 & -16.4 & -21.1 & -24.7 \\
\hline
\end{tabular}

peratures can be attributed to the weakening of the Irminger Current and the strengthening of the East Greenland Current accompanied by the retreat of the subpolar front to the south and east.

The SST observation series for the Scotian Shelf covered the period 1977-88, i.e. since Extended Jurisdiction came into effect. The Irminger Sea data were for the period 1956-88, while mean SST values were determined by month for the period 1977-85 (Table 1). Anomalies from these data were then summed on a 3-month and an annual basis. A longer time series was constructed with the mean SST values for the fourth quarter (October-December) of each year from 1962 to 1988 (Table 2). Integral curves of water temperature anomalies were compared with abundance estimates of the selected fish species.

In addition, the integral curve was constructed to show the tendencies of the water mass feature to move in the north-south direction along $35^{\circ} \mathrm{W}$ of the boundary of water with surface temperature of $10^{\circ} \mathrm{C}$ (Table 3). To construct this curve, the point of intersection of the $10^{\circ} \mathrm{C}$-isotherm with the $35^{\circ}$ meridian was read from monthly SST charts. The distance between each point and $53^{\circ} \mathrm{N}$ was calculated to within 10 miles and these monthly distances were summed by quarter and averaged for a year. The integral curve shows the intra-year and year-toyear tendency of movement of the boundary of $10^{\circ} \mathrm{C}$ water relative to $53^{\circ} \mathrm{N}$ (Gibbs' break). The drift of this water boundary can be interpreted as an approximation to the shift of the subpolar front in the north-south direction.
The $10^{\circ} \mathrm{C}$-isotherm at the sea surface was chosen because it coincides with the subpolar front and is also the southern boundary of distribution of boreal and northern boundary of distribution of tropical zooplanktonic forms. The mixed fauna zone extends southwards of this isotherm and occupies a vast space stretching in a wide band from the southwest to the northeast in the direction of the North Atlantic Current.

The depths of waters with the temperatures of $3,^{\circ} 5^{\circ}$ to $4^{\circ}$ and $5^{\circ} \mathrm{C}$, classified as the northwestern interstitial water mass by Muromtsev (1977), were determined by using the deepwater temperature observations averaged for $1951-80$ by $5^{\circ}$ Marsden trapezia. These data were compiled for this purpose by the Oceanographic Data Center (World Data Center, 1985).

\section{Results}

Published data considered in this study showed considerable fluctuations in abundance and biomass over the recent 10-30 years of the silver hake stock on the Scotian Shelf, the Newfoundland cod northern spawning stock and cod stock in the West Greenland area. Even though silver hake inhabit waters of moderate temperature while the cod prefer colder waters, the changes in biomass and abundance of these stocks followed similar trends. A dramatic drop in the late-1970s and early-1980s was followed by a sharp increase in the late-1980s. It is hypothesised here that these changes in abundance and biomass may have been related to global climatic changes of environmental factors. 
TABLE 2. Change of sum of SST anomalies in the Irminger Sea and of northern spawning cod stock biomass in the West Greenland area, 1962-88.

\begin{tabular}{lcccc}
\hline \hline & Sum of SST & \multicolumn{3}{c}{ Biomass ('000 tons) } \\
\cline { 2 - 5 } Year & anomalies $\left({ }^{\circ} \mathrm{C}\right)$ & From literature & Calculated & Deviation, \% \\
\hline 1962 & 2.45 & 1230 & 1170 & -5 \\
1963 & 2.75 & 1120 & 1120 & 0 \\
1964 & 3.55 & 1200 & 1200 & 0 \\
1965 & 4.42 & 1030 & 1060 & 3 \\
1966 & 5.82 & 860 & 840 & 2 \\
1967 & 5.82 & 800 & 840 & 5 \\
1968 & 6.32 & 780 & 760 & -2 \\
1969 & 6.62 & 730 & 710 & -3 \\
1970 & 6.85 & 570 & 670 & 17 \\
1971 & 7.52 & 570 & 570 & 0 \\
1972 & 7.25 & 580 & 610 & 5 \\
1973 & 6.58 & 480 & 510 & 6 \\
1974 & 7.35 & 300 & 380 & -7 \\
1975 & 7.86 & 170 & 0 & \\
1976 & 8.11 & 90 & 260 & 53 \\
1977 & 8.11 & 100 & 40 & -55 \\
1978 & 7.74 & 130 & 100 & 0 \\
1979 & 7.27 & 270 & 170 & 31 \\
1980 & 6.94 & 390 & 220 & -18 \\
1981 & 7.01 & 480 & 440 & 13 \\
1982 & 6.01 & 420 & 360 & -25 \\
1983 & 5.58 & 390 & 420 & 0 \\
1984 & 4.98 & 510 & 510 & 31 \\
1985 & 5.01 & 600 & 510 & 0 \\
1986 & 4.08 & 800 & 650 & 8 \\
1987 & 3.08 & 000 & 1060 & 0 \\
1988 & 3.11 & & & 6 \\
\hline & & & 000 &
\end{tabular}

TABLE 3. Sum of distances (miles) of intersection points of $10^{\circ} \mathrm{C}$-isotherm at 35 meridian off $53^{\circ} \mathrm{N}$ for the period 1976 88.

\begin{tabular}{|c|c|c|c|c|c|c|c|c|c|c|c|c|c|}
\hline Month & 1976 & 1977 & 1978 & 1979 & 1980 & 1981 & 1982 & 1983 & 1984 & 1985 & 1986 & 1987 & 1988 \\
\hline 1 & -150 & -840 & -420 & -630 & -1010 & -850 & -800 & -1780 & -1990 & -2450 & -3395 & -4235 & -4455 \\
\hline 2 & -330 & -960 & -540 & -750 & -1190 & -970 & -980 & -1930 & -2160 & -2645 & -3605 & -4465 & -4675 \\
\hline 3 & -540 & -1140 & -660 & -930 & -1410 & -1130 & -1190 & -2050 & -2330 & -2855 & -3845 & -4635 & -4805 \\
\hline 4 & -660 & -1220 & -780 & -1050 & -1540 & -1250 & -1380 & -2170 & -2420 & -3095 & -4055 & -4785 & -4925 \\
\hline 5 & -720 & -1300 & -900 & -1110 & -1300 & -1340 & -1590 & -2290 & -2510 & -3215 & -4190 & -4885 & -5045 \\
\hline 6 & -810 & -1240 & -990 & -1110 & -1120 & -1430 & -1710 & -2410 & -2610 & -3275 & -4280 & & -5045 \\
\hline 7 & -870 & -1000 & -810 & -990 & -940 & -1190 & -1530 & -2170 & -2420 & -3215 & -4190 & -4675 & -4865 \\
\hline 8 & -630 & -460 & -540 & -750 & -400 & -950 & -1260 & -1970 & -2120 & -2945 & -4060 & -4285 & -4685 \\
\hline 9 & -390 & -220 & -240 & -540 & -160 & -740 & -1150 & -1770 & -1940 & -2045 & -3805 & -4025 & -4445 \\
\hline 10 & -420 & -160 & -180 & -540 & -220 & -560 & -1210 & -1710 & -1940 & -3005 & -3805 & -4005 & -4445 \\
\hline 11 & -540 & -220 & -270 & -660 & -430 & -620 & -1330 & -1690 & -2060 & -3095 & -3925 & -4115 & -4515 \\
\hline 12 & -720 & -300 & -510 & -780 & -640 & -680 & -1660 & -1780 & -2240 & -3215 & -4125 & -4235 & -4635 \\
\hline
\end{tabular}

\begin{tabular}{|c|c|c|c|c|c|c|c|c|c|c|c|c|c|}
\hline $1-3$ & -340 & -980 & -540 & -770 & -1203 & -983 & -990 & -1920 & -2160 & -2650 & -3615 & -4445 & -4645 \\
\hline $4-6$ & -730 & -1253 & -890 & 1090 & -1320 & -1340 & -1560 & -2290 & -2510 & -3195 & -4175 & -4868 & -5005 \\
\hline $7-9$ & -630 & -560 & -530 & -760 & -500 & -960 & -1313 & -1970 & -2160 & -3035 & -4018 & -4328 & -4665 \\
\hline $10-12$ & -560 & -267 & -320 & -660 & -430 & -620 & -1380 & -1927 & -2080 & -3088 & -3952 & -4118 & -4532 \\
\hline
\end{tabular}


The sum of water temperature anomalies in the Irminger Sea SST showed a slight increase over the 1977-81 period, and a marked temperature drop over the 1982-88 period (Fig. 1). The drop was considered to be attributable to slackening of the Irminger Current and strengthening of the water of polar origin. To substantiate this assumption the characters of movement (drift) of water boundaries with the surface water temperature of $10{ }^{\circ} \mathrm{C}$ along the 35 meridian relative to $53^{\circ} \mathrm{N}$ (Fig. 2), which can be interpreted as the shift of the subpolar front in the north-south direction, were considered. From 1976 to 1981 , year-to-year fluctuations of the boundary of the waters with the temperature of $10^{\circ} \mathrm{C}$ were not well pronounced. However, considerable movement of this boundary was observed beginning in 1982 and found to intensify in the second half of the year. Maximum recorded amplitudes of these movements were in 1982, 1984 and 1985. During those years, a vast area of the Irminger Sea experienced the influence of colder waters.

During the same period, but with a 3-year delay, an inverse trend was observed for cod biomass in the West Greenland area. Cod biomass dropped from 252000 tons in 1982 to 44000 tons in 1985, and rose sharply to 613000 tons, by 1987. This represented a 14 -fold increase over 2 years (Table 4). A significant relationship was found to exist between the anomalies of the water temperature in the Irminger Sea (1974-84) and the cod biomass in the West Greenland area 3 years later. The linearregression equation was:

$$
B=41.9 \text { SST }+249
$$

where B is the biomass, and SST is the sum of SST anomalies. If this relationship holds, further decreases in the sum of SST anomalies observed

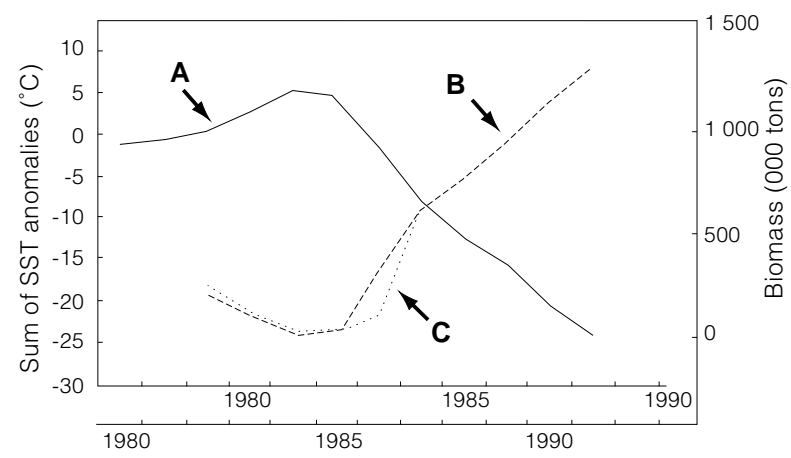

Fig. 1. Change of the sum of SST anomalies in the Irminger Sea and cod biomass in West Greenland area in 1979-87: (A) sum of SST anomalies in the center of $55-60^{\circ} \mathrm{N}, 30-35^{\circ} \mathrm{W}$ quadrant; (B) cod biomass according to Schumacher (MS 1988); and $(\mathbf{C})$ calculated values of cod biomass. during 1985-88 suggest that the cod biomass at West Greenland may be expected to increase in the forthcoming years.

The sum of SST anomalies in the Irminger Sea during the autumn/winter period of 1956 to 1977 increased from $2.45^{\circ}$ to $8.11^{\circ} \mathrm{C}$, and then decreased to $3.11^{\circ} \mathrm{C}$ in 1988 . The cod spawning stock biomass changed in phase with the temperature changes, decreasing from 1.3 to 0.4 million tons from 1962 to 1977 (Fig. 3). Correlation coefficients ( $r$ ) for the sum of SST anomalies and cod spawning stock biomass for the 1962 to 1988 period were as follows:

SST in yr i vs biomass in yr i; $r=-0.78 \pm 0.05$

SST in yr i vs biomass in yr i $+1 ; r=-0.86 \pm 0.04$

SST in yr i vs biomass in yr i $+2 ; r=-0.88 \pm 0.03$

When the spawning biomass values were plotted against the sum of the SST anomalies (Fig. 4) for the same year over period of decreasing biomass (1964-72), the point fit a straight line. The equation was:

$$
B=-159 \text { SST }+1764
$$

During the period of increasing biomass (197787, except for years 1981 and 1982) the point also fit the straight line. The equation was:

$$
B=-150 \text { SST }+1261
$$

Over a number of years (1962, 1963, 1973-76, 1981, 1982 and 1988), the point fit an intermediate line:

$$
B=-160 \text { SST }+1560
$$

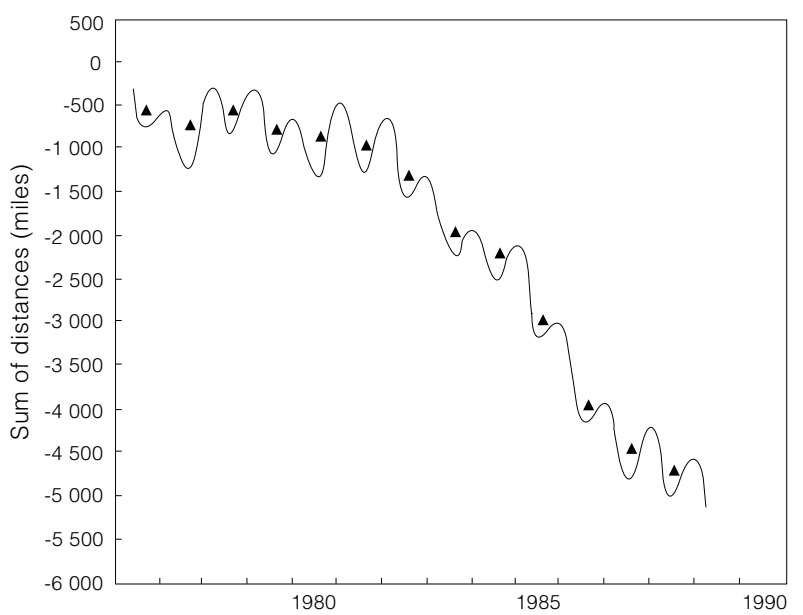

Fig. 2. Integral curve showing movement of boundary of water with the temperature of $10^{\circ} \mathrm{C}$ along 35 meridian relative to $35^{\circ} \mathrm{N}$ over the 1976 through 1988 period. 
TABLE 4. Change of sum of SST anomalies in the Irminger Sea and cod biomass in the West Greenland area (Schumacher, MS 1988) in 1979-88. (Preliminary estimates of biomass for the West Greenland area from SST in parentheses.)

\begin{tabular}{|c|c|c|c|c|c|}
\hline \multirow[b]{2}{*}{ Year } & \multirow{2}{*}{$\begin{array}{l}\text { Sum of SST } \\
\text { anomalies } \\
\left({ }^{\circ} \mathrm{C}\right)\end{array}$} & \multicolumn{4}{|c|}{ Biomass ('000 tons) } \\
\hline & & Year & $\begin{array}{c}\text { According to } \\
\text { Schumacher, MS } 1988\end{array}$ & Calculated & $\begin{array}{c}\text { Deviation } \\
(\%)\end{array}$ \\
\hline 1979 & 0.4 & 1982 & 252.4 & 232.2 & -8 \\
\hline 1980 & 2.7 & 1983 & 138.7 & 135.9 & -2 \\
\hline 1981 & 5.1 & 1984 & 34.7 & 35.3 & 2 \\
\hline 1982 & 4.6 & 1985 & 43.8 & 56.3 & 28 \\
\hline 1983 & -1.8 & 1986 & 104.0 & 324.4 & - \\
\hline 1984 & -8.7 & 1987 & 613.2 & 613.5 & 0 \\
\hline 1985 & -12.6 & 1988 & - & $(776.9)$ & - \\
\hline 1986 & -16.4 & 1989 & - & (936.2) & - \\
\hline 1987 & -21.1 & 1990 & - & $\left(\begin{array}{lll}1 & 133.1\end{array}\right)$ & - \\
\hline 1988 & -24.7 & 1991 & - & (1 283.9) & - \\
\hline
\end{tabular}

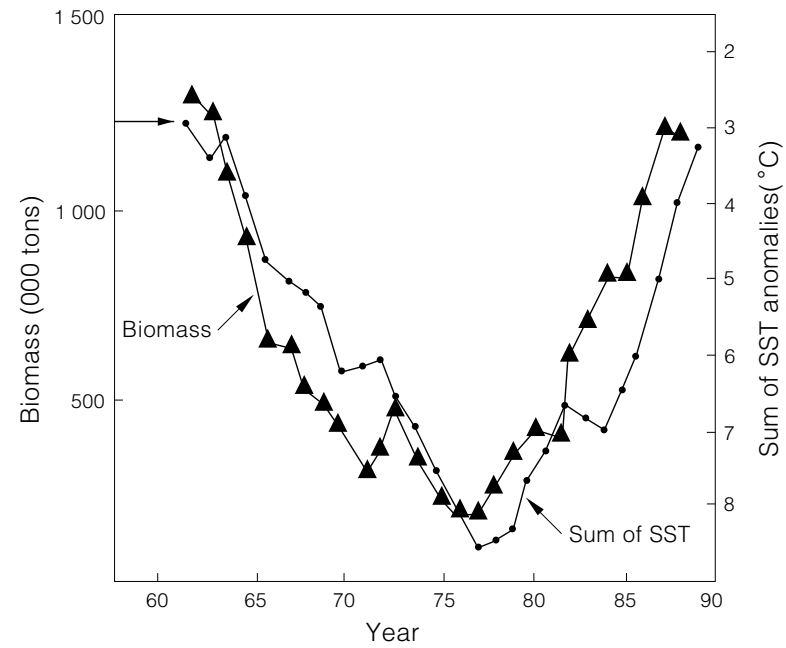

Fig. 3. Changes of sum of SST anomalies in the Irminger Sea and the biomass of Newfoundland spawning cod northern stock (Stein and Messtorff, 1990) in 1962-88.

A single regression equation for entire period for cod spawning stock biomass with a 2-year lag time was:

$$
B=-200 \text { SST }+1700
$$

Figure 4 shows that during the investigation period diversely oriented cyclic changes of the sum of water temperature anomalies in the Irminger Sea and the northern cod stock biomass took place. Since the temperature changes usually preceded those of the biomass, it appears that the trend of variations of the Newfoundland cod spawning biomass can be forecasted in approximate terms from the temperature data 1-2 years ahead.

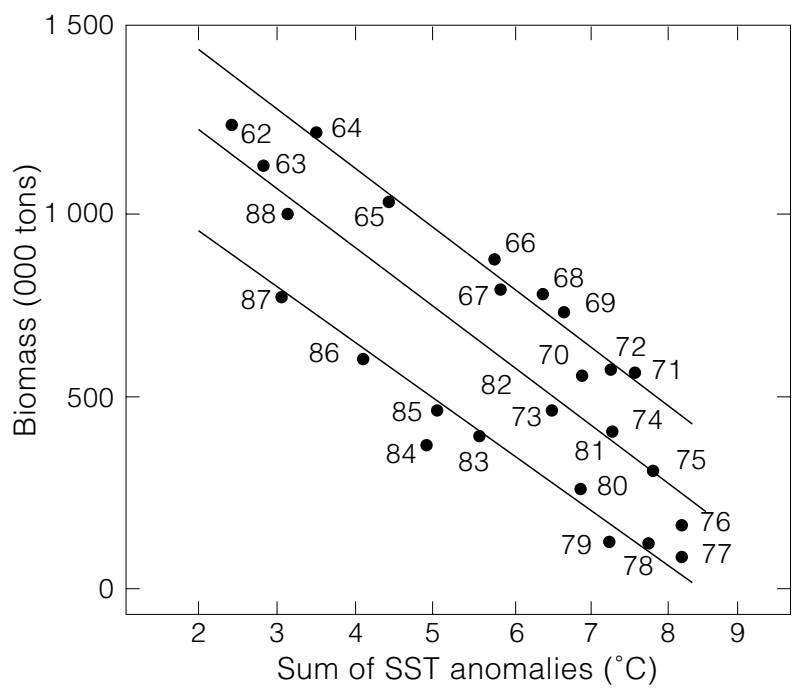

Fig. 4. Newfoundland spawning cod biomass against the sum of SST anomalies in the Irminger Sea for the 1962-88 period.

Similar analyses of correlations, between the sum of the SST anomalies and various indices of the silver hake biomass and abundance for the Nova Scotia area, have been presented by Baidalinov and Rikhter (MS 1988). They found direct relationships of the water temperature and silver hake biomass in that area. In the course of 6 years from 1974 to 1982, the water temperature changed insignificantly within the range of mean values for the considered period. The 1983-86 period was characterized by a trend which resulted in a substantial rise of the water temperatures. Table 5 shows considerable differences in these indices over the 1977-81 and the 1983-86 periods. 
TABLE 5. Change of Scotian Shelf silver hake biomass ('000 tons) and catch- per-effort in 1977-81 and 1983-86.

\begin{tabular}{lrr}
\hline \hline Indices & $1977-1981$ & $1983-1986$ \\
\hline Biomass 1+ & $143-187$ & $262-817$ \\
Biomass 2+ & $112-150$ & $209-299$ \\
Biomass in the beginning of the year & $158-193$ & $255-888$ \\
Biomass & $332-376$ & $329-676$ \\
Catch per fishing day & $20.9-29.5$ & $30.5-44.3$ \\
Catch per trawling hour & $1.21-1.90$ & $1.75-4.23$ \\
\hline
\end{tabular}
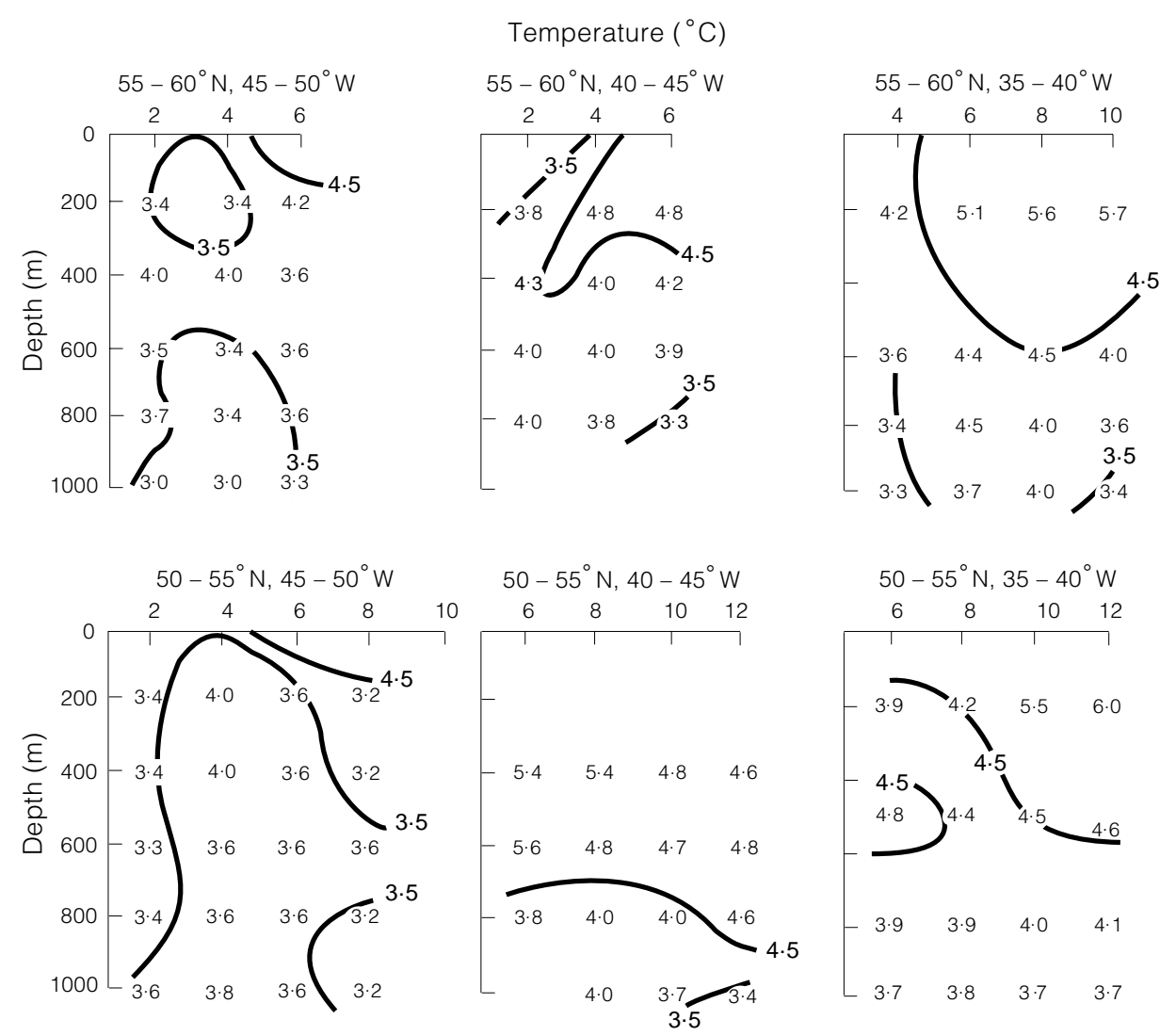

Fig. 5. Vertical water temperature distributions by $6-5^{\circ}$ quadrants in the North Atlantic. Data averaged for 1951-80 period.

\section{Discussion}

The waters of the West Greenland area is known to be influenced by the northern subpolar gyral (Stein and Messtorff, 1990). According to these authors, general features of the temperature regime on the West Greenland Banks is as follows: the water temperature changes from $1^{\circ}$ to $4.5^{\circ} \mathrm{C}$, from surface to $500 \mathrm{~m}$ and the influence of the warm constituent of the Irminger Sea waters is obvious, while in deeper waters these layers mix with the Labrador waters. So the climatic changes of the oceanolographic conditions of the waters in the Irminger Sea can be assumed to influence the water regime of the West Greenland area.

Two types of the intermediate water masses as classified by Muromtsev (1977) are of great importance to the subpolar gyral system. These are the northwestern type (temperature $3.5^{\circ}$ to $4.5^{\circ} \mathrm{C}$, salinity 34.87-34.98\%o, oxygen content 5.1-6.2 m//l) and the North Atlantic type (temperature $5^{\circ}$ to $14^{\circ} \mathrm{C}$, salinity 35.0-35.9\%o, oxygen content $4.0-5.5 \mathrm{ml} / \mathrm{l}$ ). The subpolar front passing along the western Gulf 
Stream boundary and the North Atlantic Current divides these water masses. In the subpolar front zone, the rising streams are strong. Their rate somewhat exceeds that of sinking streams, therefore, the frontal zone serves rather as the area where deep waters rise to the surface than the area of intensive water sinking. With depth, the subpolar front divides these water masses not horizontally, but vertically, having changed from the hydrological front to the interface between steadily stratified water masses (Gruzinov, 1975). The subpolar front zone is characterized by simultaneous development of different biological seasons which, combined with individual planktonic complexes in diverse water masses, provides a stable food base for the fish throughout the year (Gruzinov, 1975). In the open part of the North Atlantic, a number of vast and relatively steady (in time) regions exist. Associated with them, maximum concentrations of the zooplankton biomass related to peculiarities of water circulation in the subpolar gyral exist. One of them, the largest in the North Atlantic in terms of area, was described as located north of Newfoundland to $59^{\circ} \mathrm{N}$ and $41^{\circ} \mathrm{W}$, and occupying the entire southeastern part of the Labrador Basin (Bulatov, 1971).

Figure 5 shows the depth of the Northwest interstitial water mass markedly decreased westwardly with the drop of the surface temperature in the Irminger Sea. It is likely that the long-term decrease of the SST in the Irminger Sea results in the water being pressed upward by the Northwest interstitial water mass in the West Greenland area. It can be assumed that due to intensified contrasts (gradients) between the warm underlying layer and upper cold water layer, conditions favour the growth of the Arctic and boreal zooplanktonic forms and the other organisms which form the food base for the West Greenland cod. Blooms of such food sources appear to result in significant cod biomass increases.

In conclusion, the identification of the mechanism of influence of long-term changes of environmental factors on the dynamics of the commercial fish abundance and biomass is of great importance. Changes in the oceanolographic regime and in the faunal communities at the ecosystem level, appear to be related. Such relationships could be directly reflected in changes in biomass, particulary in the status of stock of commercially important fish species. Therefore, the monitoring of the environmental factors and the state of commercial fish stocks may be useful in the understanding of fish population abundance dynamics.

\section{References}

BAIDALINOV, A. P., and V. A. RIKHTER. MS 1988. Correlation between trends to change of sea-surface temperature, biomass and catch-per-unit effort of Scotian Shelf silver hake (Div. 4VWX) in 1977-87. NAFO SCR Doc., No. 88, Serial No. N1540, 8 p.

BULATOV, R. P. 1971. Peculiarities of plankton distribution and year-to-year variability in the subarctic gyral of the North Atlantic waters. Review information of TsNIITEIRCh. Fish. Oceanol., 9(5): 3-28.

FANNING, L. P., D. E. WALDRON, and C. BOURBONNAIS. MS 1987. Scotian Shelf silver hake population size in 1986. NAFO SCR Doc., No. 56, Serial No. N1346, 26 p.

FO'C'SLE, 1988. Protecting the spawning stock. FO'C'SLE, 8(2): $24 \mathrm{p}$

GIRS, A. A. 1971. Long-term atmospheric circulation and forecasts. M., Gidrometeoizdat: $280 \mathrm{p}$.

GRUZINOV, V. M. 1975. Frontal zones of the World Ocean. Trans. State Ocean. Inst., Vol. 123, M.: 198.

WORLD DATA CENTER, 1985. Hydrophysical parameters in energy active North Atlantic areas, All-Union Research of Hydrometeorlogical Information. Obninsk, 1: 532 p.

MUROMTSEV, A. M. 1977. Vertical structure of the World Ocean waters below the surface layer. Trudy VNIRO, 119(2): 52-53.

NOSKOV, A. S. MS 1987. Assessment of the Scotian silver hake (Merluccius bilinearis) stocks and allowable catch in 1988. NAFO SCR Doc., No. 42, Serial No. N1327, 8 p.

SCHUMACHER, A. MS 1988. Status of Subarea 1 and the fisheries. An extract of the report of the ICES Working Group on cod stocks off East Greenland, Copenhagen, 11-23 February 1988. NAFO SCR Doc., No. 45, Serial No. N1485, 37 p.

STEIN, A., and J. MESSTORFF. 1990. Are fluctuations in cod recruitment off West Greenland related to longterm variations of the physical environment. NAFO Sci. Coun. Studies, 14: 39-44.

ZVEREV, A. A. 1972. Water temperature variations in the Northern part of the Atlantic Ocean in 1948-1968. Oceanology, USSR, 12(2): 211-216. 